\title{
O jovem Nietzsche leitor de Wagner
}

\section{The young Nietzsche, a reader of Wagner}

Hélio SOCHODOLAK ${ }^{*}$

Resumo: Seguindo as pistas do jovem leitor Nietzsche em sua relação intensa e apaixonada com a música, abordamos historicamente seu envolvimento inicial com a causa wagneriana, no final da década de 1860 e inícios da década de 1870. Nas ideias e escritos de Richard Wagner os anseios nietzscheanos ecoaram em sua busca por um estilo, por uma sonoridade na palavra e por um arrebatamento do leitor. Em sua correspondência e em seus textos, percebemos um jovem filólogo(sofo) empolgado, mas, às vezes, desconfiado: Wagner representaria uma alternativa para um novo modelo cultural aos alemães na segunda metade do XIX? O músico poderia ensinar a nação a estabelecer novas relações com a palavra? Poderia ensinar a ler artisticamente?

Palavras-chave: Jovem Nietzsche. História da leitura. Século XIX. Tragicidade.

Abstract: Following clues from the young reader, Nietzsche, with regards to his intense and passionate relationship with music, we can historically approach his initial involvement in the Wagnerian cause during the late 1860s and early 1870s. The ideas and writings of Richard Wagner echoed Nietzschian concerns in his search for a style, for the sonorous quality in words, and for the enthusiasm of the reader. In his correspondence and in his writings, we see a young philologist (philosopher) excited, but sometimes suspicious: does Wagner represent an alternative to a new cultural model for the Germans in the second half of the $19^{\text {th }}$ century? Could a musician teach a nation to establish new relationships through words? Could he teach a more artistic manner of reading?

Keywords: Young Nietzsche. Reading history. $19^{\text {th }}$ century. Tragic quality.

\footnotetext{
* Professor Doutor - Departamento de História e do Programa de Pós-graduação em História - da Universidade Estadual do Centro-Oeste - campus de Irati-PR - UNICENTRO - PR 153, Km 07, CEP: 84500-000, Irati, Paraná, Brasil. Email: sochodo@gmail.com. Pós-doutorando em História - UNESP/Assis.
} 


\section{Prólogo}

Existem muitas formas de suprir a ânsia que sentimos em atribuir sentido à nossa vida. Historicamente, a vivência da leitura foi uma forma privilegiada de alçar significados que possibilitam orientações para a existência. (DARNTON, 1992, p. 232). Nossa proposição é a de que Nietzsche, tendo tido acesso e estímulo aos livros desde sua infância, utilizou a leitura como uma poderosa ferramenta para produzir significados que se modificaram ao longo da fase que denominamos o jovem Nietzsche. ${ }^{1}$

A leitura lhe serviria, algumas vezes, para acessar um conhecimento universal (conhecimentos gerais), outras vezes, um conhecimento especializado, a filologia, que também poderia servir-lhe como instrumento rigoroso de leitura. Em outros momentos, ainda, a leitura fundamentaria o convívio entre amigos (comunidades de leitores) que poderiam compartilhar ideias e valores culturais.

No processo de significação da leitura, pelo jovem Nietzsche, algo nos chamou atenção, notamos uma espécie de fio condutor que parecia resistir às mudanças: o objetivo de ler tendo em vista o autoconhecimento e o combate. Quanto melhor podia ler, melhor podia combater! A leitura se mostraria, ao jovem Nietzsche, como um caminho para a libertação de limitadores de uma autêntica cultura. Tais elementos impediam o livre-pensamento, o exercício da autenticidade, da imaginação, da criação, enfim, do ser-si-mesmo.

Acompanhemos a seguinte reflexão de Robert Darnton:

Consideremos a freqüência com que a leitura mudou no curso da história - A leitura que Lutero fez de Paulo, a leitura que Marx fez de Hegel, a leitura que Mao fez de Marx. Esses pontos se sobressaem em um processo muito mais profundo, muito mais vasto - o esforço eterno do homem para encontrar significado no mundo que o cerca e no interior de si mesmo. Se pudéssemos compreender como ele tem lido, poderíamos nos aproximar de um entendimento de como ele compreende a vida; e dessa maneira, da maneira histórica, poderíamos até satisfazer nossa própria ânsia de significado.(DARNTON, 1992, p. 234).

Num olhar atento sobre a passagem acima, podemos notar algumas das principais questões que preocupam a historiografia cultural da leitura. Em primeiro lugar, a questão da variação na forma de ler dos indivíduos, ou dos grupos sociais, ao longo da história. Em segundo lugar, a questão da procura de significados "no mundo que o cerca e no interior de si mesmo" é uma necessidade que motiva o ser humano à leitura e à representação de novos significados. Estes, quase sempre, dispostos igualmente para a leitura. Por último, a possibilidade de, ao compreender como 
os indivíduos do passado leram, compreender como eles pensaram as mais variadas questões sobre a vida. Assim, talvez possamos satisfazer nossa própria necessidade de significados.

Tais considerações nos indicam um caminho metodológico muito fértil para nos aproximarmos do jovem Nietzsche. A leitura feita por ele possui particularidades, tais como a de Paulo por Lutero, de Hegel por Marx e assim por diante. Como Nietzsche leu os textos? Que significados atribuiu a eles? Que significados estaria procurando para si e para seu tempo?

Darnton nos aponta algumas dificuldades para a compreensão histórica dos leitores de outrora. Para ele, “[...] os documentos raramente mostram os leitores em atividade, moldando o significado a partir dos textos” (DARNTON, 1992, p. 203). Entretanto, no caso do jovem Nietzsche, em muitos momentos, é possível percebê-lo em plena atividade de leitura. Disposto a comentar e acatar aquelas leituras que lhe inspirariam admiração ou lhe forneceriam orientações para a vida, tal como Hölderlin, Goethe, Emerson, Schopenhauer e Wagner. Também se mostraria voraz em combater aquelas leituras que, em dado momento, se tornariam opressoras ou dignas de sua "esgrima verbal”, a exemplo de Antiga e a Nova Fé (1872), de F. D. Strauss, que combate na Primeira Intempestiva e de A Filosofia do Inconsciente (1869), de Edward von Hartmann, contra o qual investe na Segunda Intempestiva. Além disso, as referências aos livros e às leituras são incontáveis. Elas aparecem desde a mais tenra juventude de Nietzsche, especialmente em sua vasta correspondência destinada à mãe, à irmã e aos amigos.

Concordamos com Darnton quando associa leitura e escrita, ao apontar que, na maioria das vezes, só podemos abordar os significados da leitura feita no passado valendo-nos da escrita: “e os documentos são, eles próprios, textos, o que também requer interpretação.” (DARNTON, 1992, p. 203 e passim). Entendemos, pois, não ser possível dissociar o Nietzsche leitor do Nietzsche escritor. Descobrir o primeiro é fundamental para encontrar o segundo, e vice-versa. Neste artigo, tratamos da leitura que o jovem Nietzsche fez de Wagner e seu envolvimento com uma "causa cultural.” Para tanto, organizamos o texto em três atos, seguindo uma hermenêutica histórica. Partimos das relações pessoais e afetivas dos sujeitos, imersos em sua trajetória histórica, para depois tratarmos dos significados da leitura e, por fim, dos seus usos.

\section{Primeiro ato: o encontro e a relação inicial de Nietzsche com Wagner}

A partir de setembro de 1868, um personagem tornou-se motivo de grande atenção nas cartas de Nietzsche: Richard Wagner. A Deussen ele escreveu, nestes termos: "Mesmo com demora, eu encontrei o verdadeiro santo da filologia, um verdadeiro e autêntico filólogo, finalmente um mártir [...]. Sabe teu nome? Wagner, Wagner, Wagner!” (NIETZSCHE, 1986, p.597-698)². O 
santo nesse caso é uma referência aos tipos ideais de Schopenhauer, que indica o ser autêntico que Nietzsche pressupunha ser Wagner. Um verdadeiro filólogo ao estilo de Schopenhauer, “um discípulo ou um irmão espiritual do mestre”. Note-se que repetiu três vezes o nome Wagner, pontuando a sua importância para ele ou talvez como quem suspirava de alívio, depois de um grande esforço, resultado de uma longa procura: finalmente alguém! Um santo, um mártir! Autor de ideias perigosas e revolucionárias! Se haviam esperanças para a filologia e para a renovação cultural da Alemanha, Wagner era o seu nome!

O jovem Nietzsche, antes mesmo de tornar-se professor de filologia clássica na Universidade da Basiléia (1868), já almejava revolucionar o método que lhe fornecera importantes chaves de leitura: a filologia. Para tal empresa, a ferramenta mais eficaz foi-lhe a filosofia de Schopenhauer. Nesse sentido, Richard Wagner enquanto incorporação do gênio trágico schopenhaueriano seria uma forte possibilidade a ser considerada. Suas cartas desse período revelam essa expectativa insistentemente. A Rohde, por exemplo, escreveu:

Eu li os artigos de Jahn sobre a música dando atenção prioritária no que concerne a Wagner. É preciso um pouco de entusiasmo para dar plena razão a um homem como aquele. Mesmo porque, não demonstra mais do que uma instintiva desconfiança e não escuta mais do que um ouvido semifechado. Não obstante, doulhe razão somente lá onde ele vê Wagner como representante de um diletantismo moderno que absorve e digere todos os interesses artísticos... Mas a esfera afetiva onde se encontra Wagner fica excessivamente inacessível para Otto Jahn. Ele se coloca como um herói do Grenzboten, para quem a legenda de Tannhäuser e a atmosfera de Lohengrin constituem um mundo hermético. O que eu amo em Wagner, é o que eu amo em Schopenhauer, o ar ético que respiramos neles, o aroma faustiano, cruz, morte e túmulo, etc. (NIETZSCHE, 1986, p.604).

Nietzsche se referiu a Otto Jahn, o principal rival de seu “venerável conselheiro particular”, , o professor de filologia Friedrich Ritschl, na Universidade de Leipzig. Otto Jahn era um dos assíduos colaboradores do periódico Grenzboten e escreveu, em 1866, alguns artigos sobre música. (JAHN, 1866) A atitude de Nietzsche em defesa de Ritschl não era inesperada. O que se apresentou como novo foi sua defesa em favor de Wagner. Para o jovem Nietzsche, Jahn não seria capacitado para compreender a atmosfera afetiva que envolvia a obra de Wagner. Não teria ouvidos para o inaudito: o gênio trágico schopenhaueriano que imperava ali.

Numa carta a Rohde, de 27 de outubro de 1868, Nietzsche revelou as sensações que sentira em um concerto realizado na Antuérpia, onde se executou o prólogo de Tristão e Isolda e a abertura de Os mestres cantores. Segundo Janz, este teria sido o momento da conversão plena do jovem Nietzsche ao wagnerianismo (JANZ, 1978, p. 214) ${ }^{4}$. Nas palavras de Nietzsche a Rohde: 
Frente a essa música é impossível me impor uma posição distanciada e crítica; toda fibra, todo nervo se estremece e faz muito tempo que não sentia um sentimento de êxtase como o que se apoderou de mim ao escutar esta abertura, senti-me sendo arrebatado para fora de mim. (NIETZSCHE, 1986, p.613).

De fato, a experiência que Nietzsche sentiu com a música de Wagner parece ter sido muito significativa. Uma linguagem que atingisse profundamente o espectador, tal como a música de Wagner, parecia coincidir com os desejos de Nietzsche em escrever dessa mesma forma. Schopenhauer o havia arrebatado com a sua filosofia, Wagner com sua música. Eram mestres que deviam ser seguidos, seguidos por sua forma de pensar, mas especialmente pelo exemplo. Acerca disso, Nietzsche afirmou na Terceira Intempestiva:

Estimo mais um filósofo na medida em que ele pode servir de exemplo. [...] Mas este exemplo deve ser dado pela vida real e não somente pelos livros, deve ser dado, como ensinavam os filósofos da Grécia, pela expressão do rosto, a atitude, o vestuário, o regime alimentar, os costumes, mais ainda do que pelo que se diz e pelo que se escreve. (NIETZSCHE, 1988, §3).

Dessa forma, Nietzsche teria lido, “fisiologicamente”, Schopenhauer. Seguia seus exemplos como um filho segue as orientações de um pai. A leitura só tem sentido se feita intensamente com todos os sentidos, ela não pode ser isolada do autor, portanto, para uma completa entrega e valoração. O jovem Nietzsche leu assim os textos de Schopenhauer e sentia o mesmo para com a música de Wagner. Otto Jahn não fora capaz dessa entrega, de sentir esse arrebatamento, por isso suas críticas não mereciam crédito. Dessa forma, a defesa nietzscheana de Wagner se insere no contexto de conhecimento da obra de Wagner e de convivência com a família de seu “venerável professor" Ritschl que, por sua vez, trocava amabilidades com a família Brockhaus, especialmente com Hermann, um professor orientalista, colega de Ritschl e Friedrich Brockhaus, um famoso editor.

Eram casadas com os irmãos Brockhaus duas irmãs de Wagner, Ottilie e Luise, respectivamente. Assim, por meio da convivência entre essas famílias, Nietzsche podia ouvir muitos comentários acerca de Wagner, sobre sua forma de pensar e sobre sua arte. Podemos compreender, portanto, a afetação de Nietzsche com os comentários de Otto Jahn, bem como o entusiasmo que nutriria para conhecer pessoalmente o célebre músico.

Podemos acompanhar o jovem Nietzsche descrevendo sua ansiedade e euforia com a possibilidade de conhecer pessoalmente Wagner. O desejo de conhecer o autor de Os Mestres cantores tornou-se incontrolável. Numa carta a Erwin Rohde, Nietzsche contou em detalhes os preparativos para o esperado encontro, desde os contatos com a irmã de Wagner, que iria intermediar o encontro durante uma visita de Wagner à sua casa, até os cuidados, um tanto 
atrapalhados, com a roupa nova que, por pouco, não ficou pronta a tempo! "Esta novidade me tomou completamente o pensamento [...] que eu fui pego por uma espécie de vertigem”, confessou a seu amigo. (NIETZSCHE, 1986, p.616-623).

O encontro, no relato de Nietzsche, foi muito satisfatório e rememorável! Ao que consta tanto Nietzsche quanto Wagner tiveram impressões excelentes um do outro. Vale a pena acompanhar o relato de Nietzsche acerca dessas impressões:

Antes e depois de sentarmos à mesa, Wagner tocou todas as passagens importantes de "Os mestres cantores", imitando as vozes em muito bom humor. É um homem muito vivaz e animado, sabe falar de improviso, é muito inteligente e sabe animar uma reunião íntima. Mantive com ele uma conversa sobre Schopenhauer, e já podes compreender o prazer que foi para mim ouvi-lo, com calor indescritível, falar sobre o único filósofo que conheceu a essência da música. (NIETZSCHE, 1986, p.621).

Podemos inferir que o prazer que Nietzsche sentiu ao ler Schopenhauer e utilizar essa leitura para seus interesses, a saber, o autoconhecimento e o combate, teve completa ressonância com o conhecimento dessa pessoa tão impressionante para o jovem Nietzsche: Richard Wagner. Do lado de Wagner, a visão de um jovem filósofo, conhecedor de música e filosofia, especialmente conhecedor de sua obra e de Schopenhauer, também o deixou entusiasmado. Vale citar que recomendou a Nietzsche a divulgação de sua música entre seus parentes, os Brockhaus. Tarefa que foi aceita com prazer como relata Nietzsche na carta supracitada para Rohde. Igualmente, ao despedirem-se, de acordo com a narrativa de Nietzsche, estabeleceu-se o elo para novos encontros. "No final, quando estávamos para partir, me estendeu a mão calorosamente e me convidou com muita cordialidade a visitar-lhe para fazer música e filosofia.” (NIETZSCHE, 1986, p.604).

Desde o primeiro encontro eles estabeleceram muitos pontos em comum, gostos e visões de mundo. O gosto pela música e pela filosofia de Schopenhauer foram os mais evidentes. Mas houve dois outros elementos que não podemos considerar menos importantes, trata-se da escrita wagneriana que Nietzsche pôde apreciar já neste primeiro encontro e do gosto pela polêmica, pela provocação. Segundo o relato de Nietzsche ao seu amigo Rohde, Wagner leu para Nietzsche um trecho da autobiografia que estava escrevendo. Nietzsche declarou ter gostado muito da forma da escrita em tom pessoal e confidente além da “extraordinária agilidade e inteligência” que Wagner apresentou em seu texto. Especialmente do envolvimento que provocava naquele que escutava; neste caso em particular, vontade de rir da narrativa de um ocorrido na juventude de Wagner. Este parece ser um caráter bastante apreciado nos textos de Wagner por Nietzsche: o efeito sonoro e afetivo de suas palavras. 


\section{Hélio Sochodolak}

Além dessa característica sobre a escrita de Wagner, Nietzsche observou seu contentamento com a apropriação polêmica de sua pessoa. Característica que notamos também em Nietzsche desde sua juventude. Wagner teria perguntado para Nietzsche sobre a atitude dos professores frente a ele. Nietzsche teria discorrido sobre a posição dos mesmos a partir de um congresso de Filosofia ocorrido em Praga. Wagner teria se divertido muito e chamado os participantes de Criados filosóficos, demonstrando seu gosto por provocações (NIETZSCHE, 1986, 605-606).

Estes pontos em comum significaram muito para Nietzsche. Tanto que aceitou o convite para a visita a Tribschen, em 17 de maio de 1869, logo após ter se tornado professor de filosofia clássica na Universidade da Basiléia, pelos esforços de Ritschl, e de ter renunciado à cidadania prussiana. Muitas outras visitas se seguiram a esta, aumentando cada vez mais as afinidades entre eles.

Vejamos como Nietzsche revela à sua mãe sua relação inicial com Wagner:

De máxima importância é que tenho em Lucerna um desejado e amigo e vizinho, mesmo que não suficientemente perto, mas a uma distância que permite aproveitar todos os dias livres para nos encontrarmos. Este amigo é Richard Wagner, tão grande como homem e como artista. Junto com ele e com a genial Senhora Bülow, a filha de Liszt, tenho passado dias felizes, por exemplo, o último sábado e domingo. A vila de Wagner, às margens dos Quatro Cantões e ao pé do Pilatus, em uma maravilhosa solidão, está, como podes imaginar, perfeitamente instalada; ali nós passamos em uma conversa muito sugestiva, em meio a um clima familiar delicioso e completamente à margem da acostumada trivialidade social, Ele é para mim um grande achado. (NIETZSCHE, 1986b, p.19-20).

O jovem Nietzsche encontrou um novo e provavelmente o mais significativo amigo de sua vida. $^{5}$ Mas a recíproca parece ter sido também verdadeira. Quando do lançamento da pedra fundamental do Teatro de Bayreuth, por ocasião de seu aniversário, Wagner escreveu a Nietzsche e lhe fez a seguinte revelação: "Na verdade depois de minha mulher, você é o único lucro que a vida me deu” (SAFRANSKI, 2001, p. 329-330) ${ }^{6}$.

Num outro momento, desta vez dirigindo-se a Rohde para agradecê-lo por auxiliar no combate às críticas proferidas por Ulrich von Willamowitz - Moellendorf acerca de O Nascimento da Tragédia de Nietzsche, Wagner fez as seguintes afirmações:

Acho que, com Nietzsche e através dele, estou em muito boa companhia. Você não pode saber o que significa para um homem que passou uma longa vida na companhia de pessoas inferiores ou bastante estúpidas, ser capaz de dizer, finalmente: Deus seja louvado, aqui vem um novo tipo de homem, possivelmente de uma geração inteira. Quando isto acontece, sentimo-nos recompensados por termos sido obrigados a viver, durante meio século, num manicômio. Esta mudança 
de condições só começou depois de eu ter conhecido Nietzsche. (NIETZSCHE, 1990, p. 158).

Podemos considerar a intensidade da amizade que cultivaram e os efeitos da mesma sobre eles. Wagner parece ter visto Nietzsche como um tipo humano exemplar por sua intelectualidade, profundidade e visão de mundo, mais do que um discípulo e propagandista, talvez um irmão que indicava os caminhos e os perigos. O filósofo que complementa o artista! Talvez tenha sido nessa mesma perspectiva que o jovem Nietzsche escreveria Richard Wagner em Bayreuth.

De qualquer modo, não foi apenas uma amizade, mas uma relação profunda que marcou significativamente os dois. Apenas para ilustrar mais uma vez a natureza dessa relação, poderemos mencionar outra carta em que Nietzsche, desculpando-se por não ter estado com Wagner na comemoração de seu aniversário, se referiu a ele de forma muito pessoal e íntima:

\begin{abstract}
"Pater Seraphice": [...] Permita-me dirigir-me a vós na forma mais estrita e pessoal possível, tal como desejo. Certamente outros lhe ofereceram felicitações em nome da arte sagrada, em nome das esperanças alemãs mais belas [...]; a mim é suficiente o mais subjetivo de todos os desejos: o de que continues sendo para mim o que foi no último ano, meu iniciador nos segredos da arte e da vida. Ainda que a névoa cinza da filologia não me permita contemplá-lo a não ser de forma distante, meus pensamentos estão sempre ao seu lado [...]. (NIETZSCHE, 1986b, p.115-116).
\end{abstract}

Percebemos, com base nessa carta, que Nietzsche tinha aspirações bem pessoais para com Wagner, além da defesa da causa cultural. O fato de utilizar uma designação sugerida por Goethe no final da segunda parte de Fausto em que faz menção à perda dos pais naturais e à adoção por um pai seráfico, Nietzsche anunciou o que esperava de Wagner: os indícios do caminho para uma nova e verdadeira vida! (JANZ, 1978, p. 216) Esta foi também a compreensão de Janz. Para ele:

Os homens valiosos e inteligentes que Nietzsche conheceu até o momento eram eruditos e literatos. Em Wagner encontrou, pela primeira vez, um artista criador de grande estilo que desvelou todos os sonhos e desejos que nele pulsavam amordaçados e secretos. (JANZ, 1978, p. 216).

Nietzsche encontrou, enfim, o grande homem, o gênio anunciado pela leitura de Schopenhauer. Mas não somente. Em Wagner, Nietzsche percebia a continuidade da orientação do trabalho de sua formação intelectual. Alguém que completaria o autoconhecimento e forneceria mais elementos para o combate com os elementos não-livres. Tornou-se, pois, além de schopenhaueriano, wagneriano. A vantagem de ser wagneriano consistia em ter mais claro o caminho para sua causa da renovação cultural que passaria pela música. "Junto do poder de sua música, havia, nos aponta Janz, um grande objetivo espiritual: a renovação da cultura alemã, um objetivo que já inflamava a alma de Nietzsche.” (JANZ, 1978, p. 217). A direção para o combate 
estava dada! E a leitura deveria subsidiar com as armas/ferramentas a luta contra os elementos nãolivres da cultura alemã.

Dessa forma, Nietzsche passou a ler os poemas de Wagner e seus escritos estéticos dos anos de 1849 até 1851, especialmente a então recém-publicada segunda edição de Ópera e Drama, que intensificou sobremaneira sua crença na possibilidade de renovação da cultura alemã. (JANZ, 1978, p. 217) Procurou envolver outras pessoas nesse processo, especialmente seu amigo e correspondente Rohde. Incentivou-o a ler Ópera e Drama e jubilou quando recebeu o retorno e pôde notar, também, o entusiasmo no amigo que fez os seguintes elogios: “[...] a mais feliz imagem da natureza artística plena e criadora [...] idéia de uma arte capaz de representar em uma imagem pura o mundo inteiro, a vontade e o intelecto a um só tempo.” (JANZ, 1978, p. 218) ${ }^{7}$ Então Nietzsche comentou com ele:

Wagner é, tal como o conheço agora a partir de sua música, de seus poemas e de sua estética, e não em menor medida daquele feliz encontro com ele, a mais viva ilustração do que Schopenhauer chama de um gênio [...] Quisera que pudéssemos ler juntos seus poemas, [...]; poderíamos seguir o curso audaz e vertiginoso de sua estética revolucionária e construtiva; poderíamos enfim, deixarmos nos arrebatar pelo ímpeto e riqueza de sentimentos de sua música, por esse mar tonal schopenhaueriano cuja marulhada mais secreta percebo e faço meu, de um modo que posso dizer que minha audição da música wagneriana é uma jubilante intuição, incluindo uma experiência, de enorme intensidade: por ela me encontro a mim mesmo. (NIETZSCHE, 1986, p.630).

O leitmotiv, permitamo-nos usar uma alegoria wagneriana, do autoconhecimento aparece nessa referência, como podemos notar. Os escritos estéticos do jovem Wagner estariam, além de sua própria música, auxiliando o jovem Nietzsche em sua trajetória interior. Estaria provocando-lhe jubilantes intuições, a tal ponto de confundir a música wagneriana com o som de seu interior. O barulho do mar que o alegrava por ser schopenhaueriano... Por outro lado, também o leitmotiv da luta e da causa cultural aparece, a nosso ver, não por acaso, associado ao do autoconhecimento. O jovem Nietzsche destacou o que achava importante nos escritos do jovem Wagner: "o curso audaz e vertiginoso de sua estética revolucionária e construtiva”.

Esta parece ser uma leitura singular que Nietzsche fizera de seu encontro com a obra e a pessoa de Wagner. E tanto Nietzsche levou a sério o caráter revolucionário e construtivo do wagnerianismo, que foi este um dos principais motivos de seu rompimento posterior com o músico. Poderíamos dizer que Nietzsche levou Wagner mais a sério do que o próprio músico o fizera. Isso nos leva a investigar sobre as significações que o jovem Nietzsche fez de seu novo mestre. Afinal, quem era o Wagner de Nietzsche? 


\section{Segundo ato: significados da leitura de Richard Wagner para o jovem Nietzsche}

Acreditamos que, se levarmos em conta os vários momentos da produção, sobretudo a teórica, de Richard Wagner, ${ }^{8}$ podemos compreender melhor as apropriações que o jovem Nietzsche fez da leitura de seu maior amigo. ${ }^{9}$ Para Hollinrake, por exemplo, corroborando a informação que colhemos de Janz, a produção de Wagner mais estimada por Nietzsche no início de sua convivência com o músico foram os escritos de 1849-1851 (HOLLINRAKE, 1986, p. 43-58). Fixemos nossa atenção no contexto da produção desses textos para compreendermos melhor as da sedução que eles exerceram sobre o jovem Nietzsche.

Com a finalidade de estabelecer o contexto da emergência de O Anel dos Nibelungos ao menos em projeto para Wagner, Hollinrake seguiu uma pista fornecida pelo músico ao afirmar, para Cosima, que não teria conseguido conceber $O$ Anel dos Nibelungos se não fossem os acontecimentos da Primavera de 1848 (HOLLINRAKE, 1986, p. 48). Direcionando seu olhar para o Wagner daquele momento, ele nos apresenta o músico completamente engajado politicamente.

A fermentação política pairava no ar durante sua juventude em Leipzig, onde as notícias do golpe de Estado de Lafayette, na Revolução de Paris de julho de 1830, redundaram em choques violentos entre os estudantes e a polícia, nos quais ele se lançou com envolvimento característico. Em Dresden, o turbilhão da década de 1840, culminando no fracassado levante de maio de 1849, também atraiu o jovem Kapellmeister da corte para o seu vórtice. As primeiras obras em prosa e o primeiro rascunho de $\mathrm{O}$ Anel foram inevitavelmente marcados pelos acontecimentos desses anos turbulentos, durante os quais Wagner alistou-se na Guarda comunal e consolidou amizades com o anarquista-aristocrata russo Mikhail Bakunin (um ano mais moço do que ele, vivendo então em Dresden com o nome suposto de Dr. Schwars), August Röckel (diretor musical em Dresden e editor do democrático Sächsische Volksblätter) Gottfried Semper, o arquiteto e outros revolucionários. (HOLLINRAKE, 1986, p. 48).

O engajamento no levante de Dresden, custou a Wagner o exílio em Zurique a partir de 1849. Torna-se fundamental, além de destacar essa vida política intensa e comprometida, pontuar algo que viria marcar profundamente seus escritos posteriores, especialmente no exílio. Trata-se do encontro com a obra de Ludwig Feuerbach por intermédio de um padre católico e líder político alemão, Mensdorff. Em O caso Wagner, ao diferenciar dois momentos da obra de Wagner, Nietzsche valorizou esta influência sobre o conceito de beleza, determinante na obra artística de Wagner.

Para Hollinrake:

[...] o livro de Feuerbach de 1843, Grundsätze der Philosophie der Zukunft (Princípios de Filosofia do Futuro), deflagrou as especulações de Wagner acerca da arte do futuro: Das Kunstwerk der Zukunft (A obra de arte do futuro) foi dedicada 
ao filósofo em termos calorosos na primeira edição de 1849 [...] Mensch der Zukunft (homem do futuro) e termos semelhantes são preponderantes nos escritos do período de Dresden. O lema Zukunftsmusic (música do futuro, tal como Zukunftsphilologie (filologia do futuro) aplicado a Nietzsche foi um termo feuerbachiano [...]. (HOLLINRAKE, 1986, p. 49).

Essa atração de Nietzsche pelos escritos feurbachianos de Wagner pode parecer estranha, a princípio, especialmente se levarmos em conta que o que mais atraiu Nietzsche em Wagner, como vimos, foi sua devoção a Schopenhauer. Entretanto, de acordo com Janz, o jovem Nietzsche não via contradição nesse fato. (JANZ, 1978, p. 219) Somente nos textos de Nietzsche a partir de Humano, demasiado humano é que essas questões terão maior relevância. Para o momento, vale destacar que uma das características mais importantes admiradas nessa leitura de Wagner por Nietzsche parece ser mesmo o engajamento político do artista, não só em teoria, mas na prática. Wagner defendia não só questões políticas, mas questões culturais e ostentava a convicção de que elas estavam unidas. Desse modo, Wagner

[...] refletia uma consciência genuína do movimento em prol da reforma social e sua simpatia pelo mesmo. Sem dúvida, a sua preocupação era com o papel do artista na sociedade e com as possibilidades de uma dramaturgia nacional ressurgente como foco da vida cultural. Entretanto, ao adotar a postura de um revolucionário total, defendendo vigorosamente uma nova "Lebensgemeinschaft" (comunidade vital) e o advento de uma nova elite, os "homens do futuro" de Das Kunstwerk der Zukunft (A obra de arte do futuro), ele ajudou a atiçar a chama do socialismo e deu notável contribuição para uma guerra ideológica. (HOLLINRAKE, 1986, p. 50).

Essa perspectiva aparece literalmente no texto de Nietzsche sobre o teatro de Bayreuth. A construção desse teatro significou, para o jovem Nietzsche, não uma reforma restrita à forma de fazer teatro em seu tempo, mas a reforma do próprio homem moderno. A arte aparece como pivô de uma causa revolucionária maior: revolucionar toda a cultura, toda a forma de ser e pensar na modernidade. Para Nietzsche:

[...] em nosso mundo moderno as coisas estão em uma tal relação de interdependência que, basta tirar um prego para provocar o desmoronamento de todo o edifício. [...] De forma que, é impossível atingir completo sucesso na arte cênica, sem inovar tudo, os costumes e o Estado, a educação e a vida social. [...] hoje a arte é um signo de degeneração desta vida e os teatros são humilhantes tanto para quem os constrói, como para quem os freqüenta [...]. (NIETZSCHE, 1988, p.4).

Como podemos notar, o jovem Nietzsche foi partidário de uma causa cultural revolucionária com amplas pretensões, não só artísticas, mas também políticas e ideológicas. A arte wagneriana se mostrava como um caminho para essa tarefa, e Bayreuth o início. Ao se reformar o 
teatro, Nietzsche esperava que Wagner (o gênio autêntico de Schopenhauer) pudesse purificar com sua arte todos os elementos vivos da cultura. Ele usa um termo médico para a força plástica que acreditava ser Wagner seu detentor: poder adstringente. Wagner seria o antípoda do historiador erudito, aquele capaz de produzir significados para a vida com a sua mensagem artística (NIETZSCHE, 1988, p.4). Enfim, através da arte, especialmente da música e de uma leitura artística, inseridas nas brechas do edifício moderno, poderia ser possível pôr em causa todo o edifício da chamada civilização moderna (NIETZSCHE, 1988, passim).

Mas, para isso, era preciso formar um público capaz de frequentar esse novo teatro e a arte do futuro: daí a necessidade, muitas vezes expressa por Nietzsche, de formar uma comunidade de leitores e frequentadores dessa nova visão de arte. A ideia de uma comunidade cultural tendo Wagner e Schopenhauer como alicerces.

Dessa forma, podemos pensar que uma das causas que fizeram Nietzsche admirar, indicar e comentar com seus amigos os escritos de exílio de Wagner, certamente tenha sido este caráter engajado e militante do artista. O compromisso com uma causa maior que toma a arte como meio. ${ }^{10}$ Outra causa evidente é a relação que os textos estabelecem com os gregos.

E, nesse ponto em particular, encontra-se não somente uma questão musical e artística em comum. É a partir do confronto com a ordem estabelecida que o jovem Nietzsche articulou Schopenhauer, Wagner e os gregos, pensando propostas e possibilidades para uma autêntica cultura. Associou também filosofia e arte como forças promotoras da saúde e da inocência, capazes de gerar novos valores.

A filosofia pode ensinar pelo exemplo, muito mais do que pelas palavras, assim como Schopenhauer e Wagner foram capazes de o fazer. Por meio deles, os gregos poderiam ensinar a modernidade a desenvolver uma outra visão de mundo diferente daquela otimista burguesa. “Toda reflexão wagneriana sobre a arte está associada a uma apreciação da cultura grega e a uma crítica à cultura operística que vigorava na Europa desde os séculos XVI e XVII.” (GONÇALVES DA SILVA, 2003, p. 53).

Refletem essa questão os escritos do exílio já mencionados, especialmente $A$ arte e a revolução e Ópera e Drama. No primeiro, Wagner apresentou a arte originando-se do reflexo do povo com sua alegria de viver, vinculando, pois, a arte com o meio social em que é gerada. Fazia assim, uma ácida crítica à arte moderna que se rendia à indústria, ao lucro financeiro e somente ao entretenimento do público (GONÇALVES DA SILVA, 2003, p. 51 et seq) ${ }^{11}$. No segundo escrito, Wagner apostou numa comparação entre a gênese da ópera no Renascimento italiano e o drama musical grego. Para Wagner, os italianos isolaram a arte do povo e, ao tentar recriar a tragédia Ática, o fizeram de forma artificial e caricaturesca, sem alcançar, portanto os objetivos daquele tipo 
de arte. Ao contrário, “[...] a proposta wagneriana era a de investigar as condições gerais da criação do drama grego, conhecer os fatores e as circunstâncias que o possibilitaram, não para tentar repetilo e restaurá-lo, mas para, a partir do conhecimento dessas condições, propor uma nova obra de arte.” (GONÇALVES DA SILVA, 2003, p. 53). Tratava-se de imitar os gregos como eles próprios imitavam, ou seja, criativamente. $^{12}$

Em O nascimento da tragédia, Nietzsche irá perseguir esta premissa pedagógica voltada para os gregos e, valendo-se da concepção wagneriana de arte expressa em A arte e a revolução, desejará identificar a origem da tragédia grega. Rosa Maria Dias, em Nietzsche e a música, faz uma excelente leitura de $O$ nascimento da tragédia e, em seu segundo capítulo, mapeia a preocupação de Nietzsche em situar a gênese do drama trágico na canção popular (DIAS, 1994).

Em 1870, em um pequeno ensaio intitulado O drama musical grego que, somado a outros do período tais como A visão dionisíaca do mundo e Sócrates e a tragédia que constituem o núcleo central das ideias expressas em $O$ nascimento da tragédia, o jovem Nietzsche apresenta, explicitamente, sua tese acerca da origem do drama ático. Para ele, o drama nasce a partir das festividades e dos jogos de carnaval que marcavam o início da primavera. Sem qualquer influência castradora moral, os imensos e cada vez maiores cortejos em homenagem a Dionísio, entravam nas vilas cantando, dançando, pulando, celebrando a vida. Esses costumes teriam sobrevivido mesmo durante a Idade Média nas danças juninas de São João e Santo Guy, sobre as quais a Igreja não tinha como exercer controle, mesmo tentando moralizar os cortejos com cantos e orações de aspectos fúnebres e castradores. Para Nietzsche:

Foi por essa turbulência e essa caprichosa exuberância que os primeiros passos do drama foram dados na turba excitada; transformados em sátiros e em silenos, a face coberta de fuligem, de vermelho ou do corante de diversas plantas, errando pelos campos e pelos bosques: o efeito arrebatador da primavera se manifesta bruscamente, ela exalta ao máximo as forças vitais, as visões, a crença e o encantamento; assim vão os seres em uníssono pelos campos. Este é o berço do drama. (NIETZSCHE, 1975, p. 22).

Nietzsche destacou, assim, a origem dionisíaca do drama grego nos festejos populares em homenagem ao deus-bode. Nesses cortejos dionisíacos ocorre a religião (religare) do indivíduo com a natureza que o assimila. Trata-se de um esquecimento de si-mesmo, uma negação do eu individual para a composição de um outro ser. O espetáculo maior do drama: "Nesse estado onde a gente se encontra fora-de-si, nesse estado de êxtase, [...] vemos estremecer o sol da crença na indissolubilidade e na rigidez do indivíduo.” (NIETZSCHE, 1975, p. 22). Nos parece que, nesse ponto, o jovem Nietzsche estava chamando a atenção de seu “músico-guia” que destacou o papel apolíneo na gênese do drama ático. 
Para Wagner, em A arte e a revolução, o ideal de liberdade e de beleza desenvolvido pelos gregos se sintetizava na imagem de Apolo.

Apolo era, para Wagner, a representação do próprio povo grego. O ideal de beleza, força e liberdade, personificado pelo deus, era o que havia de mais nobre e elevado na consciência da sociedade grega. Apolo é por isso considerado por Wagner como o ponto fundamental da produção dramatúrgica grega. O papel inspirador de Dioniso é apenas mencionado ligeiramente. (GONÇALVES DA SILVA, 2003, p. 56).

Em A arte e a revolução podemos ler que:

Depois de ter triunfado sobre a rude religião natural asiática e de haver galgado ao cume de sua própria consciência religiosa, o gênio grego, na época de seu florescimento, manifestou na política e na arte, o homem livre, forte e belo, que encontrou sua expressão mais perfeita em Apolo, o deus da sabedoria, o deus nacional da raça helênica. (WAGNER, 1909).

Gonçalves da Silva destaca, também, a seguinte passagem de $A$ arte e a revolução que reproduzimos:

No drama grego, os feitos dos deuses e dos homens, os seus sofrimentos e alegrias, anunciados de modo grave ou jubiloso na essência superior de Apolo sob a forma do ritmo eterno, da harmonia eterna de todo o movimento e de todo o existir, tornaram-se coisa real e verdadeira. (WAGNER, 1983, p. 275).

Evidencia-se, com base nestas citações, que a ênfase da análise wagneriana sobre o drama grego fica centrada na figura do deus que vencera o dragão do caos Píton e que estabelecera o belo, o sóbrio e o organizado como expressão do espírito helênico. Apesar de não localizarmos no jovem Nietzsche nenhuma referência direta a esta visível contradição entre ele e seu Pater Seraphice, uma vez que um destaca o papel central de Dionísio, o outro de Apolo acerca da origem e da essência do drama grego. Percebemos que, acerca dessa questão, Nietzsche não seguiu inteiramente o teórico Wagner, ao contrário, enfatizou em seus textos do início da década de 1870, culminando em $O$ nascimento da tragédia, o papel do dionisíaco e do apolíneo numa relação de essencialidade versus aparência. Essa convicção, em detrimento das assertivas dos escritos wagnerianos de 1849-1851, parece ser uma das poucas que Nietzsche jamais negaria. Por exemplo, em sua Tentativa de autocrítica, um prefácio para a edição de 1886, Nietzsche reconhece: “Sim, o que é o dionisíaco? Nesse livro há uma resposta a essa pergunta - um 'sabedor' fala aqui, o iniciado e discípulo de seu deus.” (NIETZSCHE, 1992, p. 17). Por outro lado, algumas questões apresentadas pelo jovem Nietzsche relacionadas ao drama grego e sua potência pedagógica e revolucionária para a 


\section{Hélio Sochodolak}

modernidade parecem ser nitidamente inspiradas por Wagner, a exemplo da música como linguagem.

\section{Terceiro ato: música e palavra}

O jovem Nietzsche compartilhou prazerosamente com Wagner de uma concepção schopenhaueriana de música. Para Rosa Maria Dias e Gérard Lebrun, Nietzsche percebeu que Schopenhauer inaugurou uma nova maneira de compreender a música: Antes de Schopenhauer, pensava-se que a música nos proporcionasse a mesma forma de prazer que as belas formas; julgavase a música conforme a mesma ideia de beleza que se usava para as artes plásticas (LEBRUN, 1995, p. 41; DIAS, 1994, p. 24).

Nessa direção, o jovem Nietzsche, motivado pela leitura de $O$ mundo como vontade $e$ representação e pela causa revolucionária artística de Wagner, escreve sobre a música em $O$ nascimento da tragédia, citando seu mestre pessimista: “[...] ela não é, como todas as demais (artes), reflexo (Abbild) do fenômeno, porém reflexo imediato da vontade mesma e, portanto, representa, para tudo o que é físico no mundo, o metafísico, e para todo o fenômeno, a coisa em si.” (NIETZSCHE, 1992, p. 97) ${ }^{13}$. A música é entendida não como reflexo do reflexo (fenômeno), mas como reflexo da coisa-em-si, dessa forma, pode ser utilizada, enquanto linguagem universal, como alternativa à linguagem matemática adotada pela ciência como paradigmática. (NIETZSCHE, 1992, p. 99) Completa Nietzsche: "Poder-se-ia, em conseqüência, chamar o mundo todo tanto de música corporificada quanto de vontade corporificada.” (NIETZSCHE, 1992, p. 17).

Para Nietzsche, apesar de sentir maior atração pelos textos de Wagner em sua fase feurbachiana (1849-1851), será no Beethoven que Wagner saberá sintetizar sua posição sobre a música com genialidade. Para Nietzsche, segundo Wagner “[...] a música deve ser medida segundo princípios estéticos completamente diferentes dos de todas as artes figurativas e, desde logo, não segundo a categoria da beleza.” (NIETZSCHE, 1992, p. 98). Na leitura de Rosa Maria Dias tal tema poderia ser sintetizado assim:

A música, pelo seu caráter extático, libera o homem temporariamente da vontade individual e o deixa dominado pela natureza; uma emoção desmesurada se apodera de todo o seu ser e desperta nele sentimentos obscuros que não podem ser explicados pela categoria da beleza. (DIAS, 1994, p. 24).

Nesse sentido, não importa ser a música bela, mas arrebatadora, como é a vontade, esta que quase nunca é bela, mas invariavelmente responsável pelas Dores do mundo. ${ }^{14}$ Digna de nota é a significação do jovem Nietzsche por ocasião de seu primeiro contato com o livro de Wagner sobre 
Beethoven. Escreve em 7 de novembro de 1870 uma carta a Gersdorff, comunicando duas excelentes notícias de Tribschen: a primeira foi o casamento de Wagner e Cosima que ocorrera em agosto e que Nietzsche, mesmo tendo sido convidado para testemunha, não pôde prestigiar por estar na França. A outra se refere ao texto de Wagner:

Wagner me enviou por estes dias um maravilhoso manuscrito intitulado 'Beethoven'. Temos lá uma profunda filosofia da música, em estrita ligação com Schopenhauer. Este texto, feito em honra de Beethoven, será a melhor homenagem que lhe possa render a nação. (NIETZSCHE, 1986b, p.144).

O manuscrito de Beethoven não só foi uma ótima notícia, como confirmava as ideias sobre música de Schopenhauer, de que a música não poderia ser avaliada pelos mesmos critérios que as demais artes e que, sobretudo, consistia em uma linguagem universal. ${ }^{15}$

Em Wagner podemos ler o seguinte:

Mais foi Schopenhauer o primeiro que reconheceu e definiu, com uma claridade filosófica, a posição da música em relação às outras artes [...]. Partindo do fato admirável de que a música fala uma língua que todos podem compreender imediatamente e sem a necessidade de intermediário [...].

E ainda

Aqui o mundo exterior nos fala de um modo tão inteligível porque traz ao nosso ouvido, por meio da impressão sonora, o que pedimos a ele do mais profundo do nosso ser. O objeto do som que percebemos coincide de modo imediato com o sujeito do grito que proferimos. (WAGNER, 1987, p. 24).

Sem dúvida, Nietzsche achou o manuscrito sobre Beethoven maravilhoso e significativo. Juntamente com Schopenhauer, Wagner parecia fornecer a sustentação para uma comunidade cultural de leitores preocupados com a revolução da cultura alemã a partir da música que, com a sua linguagem não-verbal, inspira a escrita. Escrever como tocar, encontrou na “comunidade” e em Wagner a possibilidade real de concretização. ${ }^{16} \mathrm{~A}$ música atinge diretamente e sem intermediários seu ouvinte, assim como o gemido de prazer ou de dor, o grito ou o riso que, mesmo incompreensíveis gramaticalmente, comunicam diretamente ao espírito humano o seu significado. De fato, a música é universal, concluiu Nietzsche, cumpre exemplarmente a sua função no drama trágico dos gregos que souberam equacionar sabiamente música e palavra. Essa temática marcou profundamente os textos de Nietzsche durante a década de 1870, ao menos até a Quarta Intempestiva. 
Em O drama musical grego, Nietzsche defendeu a harmonia buscada pelos gregos antigos entre a música e a poesia, com base nas canções populares que originaram a tragédia. Para ele, isso ocorreu porque, dosando a influência instrumental vinda da Ásia, eles mantiveram algumas características fundamentais. Em primeiro lugar: “A verdadeira música grega é puramente vocal: o lugar natural entre a língua das palavras e aquela dos sons não foi ainda rompido: a tal ponto que o poeta era necessariamente o compositor de sua canção.” (NIETZSCHE, 1975, p. 28). O que opõe ao isolamento moderno das artes, que Nietzsche exemplificou com a separação entre o livro, sem sonoridade, e a música instrumental, essa sem palavras. Quando estão juntas, música e palavra, encontram-se artificialmente unidas e não se harmonizam. Dessa forma, "Nós achamos suportável o texto mais absurdo se a música é bela: um grego acharia isso a pura barbárie.” (NIETZSCHE, 1975, p. 29).

Em vários momentos, Nietzsche apontou para a necessidade de sonoridade nos textos. Por exemplo, sugeriu algumas vezes a prática da leitura em voz alta com seus amigos. Destacamos a carta que citamos anteriormente enviada para Rohde, em 9 de dezembro de 1868, na qual Nietzsche desejava se encontrar com o amigo para ler Wagner: “Quisera eu que pudéssemos ler juntos seus poemas”, afirmou ele ao amigo (NIETZSCHE, 1986, p.632). Também escreveu, novamente para Rohde, em dezembro de 1875 comentando o prazer que sentia quando, tendo que descansar seus olhos que doíam muito com a leitura, ouvia sua irmã lendo para ele, por exemplo, os poemas e novelas de Walter Scott. Leitura em voz alta, partilhada, sorvida lentamente, leitura musical?

Outras duas características, levantadas por Nietzsche, do drama grego foram: “[...] a simplicidade, até mesmo a pobreza de sua harmonia e a riqueza de seus meios de expressão rítmicos.” (NIETZSCHE, 1975, p. 29). Wagner fez considerações semelhantes em seu Beethoven, ao pensar como, historicamente, a música se encontrava harmonicamente relacionada à fala e à poesia como meios de expressão e construção dos mitos que se modificavam criativamente nessa relação. O músico defendeu a ideia de que a escrita vai cristalizando a interpretação e a criação, impedindo o desenvolvimento do mito e consequentemente, sua capacidade simbólica.

Para o jovem Nietzsche, em $O$ nascimento da tragédia, somente na música o mito encontra uma expressão adequada, da mesma forma que ele exerce sobre a música a função de proteger seu espectador. Assim, “a tragédia interpõe, entre o valimento universal de sua música e o ouvinte dionisiacamente suscetível, um símile sublime, o mito, e desperta naquele a aparência, como se a música fosse unicamente o mais elevado meio de representação para vivificar o mundo plástico do mito.” (NIETZSCHE, 1992, p. 125). E, sobre uma das funções centrais do mito na tragédia completou: “O mito nos protege da música, assim como, de outro lado, lhe dá suprema 
liberdade” (NIETZSCHE, 1992, p. 125) ${ }^{17}$. Ou seja, música e mito se completariam, ela lhe conferiria significado muito mais do que a palavra ou a imagem o poderiam fazer. O mito, por sua vez, protegeria o espectador da música fornecendo-lhe plena liberdade, enfim. De sua interação, derivaria o supremo prazer "ao qual conduz o caminho que passa pela derruição e negação, de tal forma que julga ouvir como se o abismo mais íntimo das coisas lhe falasse perceptivelmente.” (NIETZSCHE, 1992, p. 125).

Vale a pena dar lugar a uma das reflexões de Wagner, extremamente ilustrativa da afinidade entre ele e Nietzsche acerca disso. Com a escrita:

A arte poética passa a ser a arte de enfeitar os velhos mitos que já não podem ser inventados e termina por transformar-se em retórica e dialética. Imaginemos agora o salto da escrita à imprensa. Nos preciosos livros manuscritos o chefe de família lia em voz alta para os seus ouvintes. Agora, no livro impresso, cada um lê em silêncio para si mesmo, e é para estes leitores que o escritor escreve. Convém lembrar as seitas religiosas na época da Reforma, suas discussões e seus panfletos, para se ter uma idéia da violenta loucura que se apossou daquelas cabeças obcecadas pela letra. Pode-se admitir que o magnífico coral de Lutero preservou a saúde espiritual da Reforma, por ter definido o sentimento e curado os cérebros humanos da loucura da letra. O gênio de um povo, entretanto, podia entender-se com o impressor, por mais deplorável que fosse a ação deste último sobre ele. Mas, com a invenção dos jornais e com a evolução do jornalismo, este bom espírito do povo foi obrigado a afastar-se completamente da vida. Porque hoje em dia só vemos reinarem opiniões declaradamente "públicas" das quais algumas se conquistam com dinheiro, como as mulheres públicas. Aquele que compra regularmente um jornal encontra impressa no papel a sua própria opinião. Já não tem necessidade de pensar nem de refletir, porque ali está, preto no branco, o que outros pensaram por ele sobre Deus e sobre o mundo. Assim o jornal parisiense de modas diz também à "mulher alemã" como ela deve se vestir. Porque o francês, nestes assuntos, adquiriu plenamente o direito de nos dizer o que devemos fazer, pois é ele mesmo que ilustra a cores o nosso mundo de papel de jornal. Se compararmos a transformação do mundo poético, em uma época de literatura jornalística, à transformação que o mundo sofreu em sua forma e em seu colorido, chegaremos a um resultado perfeitamente semelhante. Quem pretenderia ser capaz de fazer uma idéia justa da grandeza e do sublime divino no mundo plástico da antiguidade grega? (WAGNER, 1983, p. 82-83).

Wagner e Nietzsche perceberam nitidamente e de forma muito semelhante as mudanças que se operavam na forma de ler em seu tempo. De forma que, o texto citado acima, bem poderia ter sido escrito pelo jovem Nietzsche. São muitos os aspectos do texto wagneriano que poderiam ser relacionados com as preocupações do jovem Nietzsche, como por exemplo, a crítica à forma moderna e apressada de ler e a leitura jornalística discutida por Nietzsche, sobretudo em suas Conferências sobre o futuro de nossos estabelecimentos de ensino e na Primeira Consideração Intempestiva: David Strauss crente e escritor. Inquieta o jovem Nietzsche o fenômeno moderno da leitura silenciosa e isolada sem a troca de impressões. Outro aspecto importante se refere aos 


\section{Hélio Sochodolak}

franceses como produtores de modismos seguidos pelos alemães que, sem autenticidade e criatividade, imitavam tais convencionalismos, essa foi uma discussão intensa na Segunda Intempestiva: da utilidade e dos inconvenientes da história para a vida. Acima de tudo Wagner aponta para a decadência da poesia com a forma jornalística de escrever. A impossibilidade de uma sonoridade reparadora da "saúde”, como a que o coro de Lutero fora capaz de praticar. Esse último aspecto nos remete, diretamente, ao Nascimento da tragédia e à função do coro no drama musical grego que Nietzsche relaciona às características dessa arte originária em sua conferência sobre o tema, a lembrar: harmonia entre música e palavra, simplicidade e riqueza rítmica de expressão.

Em O nascimento da tragédia, Nietzsche expressou efusivamente a relação entre música e palavra para os gregos. Para ele, o diálogo entre a canção popular (Volkslied) e a poesia não depreciou nenhum dos dois elementos, nem o apolíneo da poesia épica, nem o dionisíaco da canção popular. Ao contrário, promoveu o métron entre ambas. Para o jovem Nietzsche “A canção popular, se nos apresenta como espelho musical do mundo, como melodia primigênia, que procura agora uma aparência onírica paralela e a exprime na poesia.” (NIETZSCHE, 1992, p. 49). Mais adiante complementou:

Na poesia da canção popular vemos, portanto, a linguagem empenhada ao máximo em imitar a música [...]. Com isso assinalamos a única relação possível entre poesia e música, palavra e som: a palavra, a imagem, o conceito buscam uma expressão análoga à música e sofrem agora em si mesmos o poder da música. Nesse sentido nos é dado distinguir na história lingüística do povo grego duas correntes principais, conforme a linguagem imite o mundo da aparência e da imagem ou o da música. (NIETZSCHE, 1992, p. 49).

Percebemos que a música exerce papel predominante na perspectiva da canção popular, segundo nossos autores, uma vez que, sendo linguagem universal por excelência, a palavra, a imagem e o conceito podem imitá-la partilhando dessa forma, de sua universalidade. Para Nietzsche a canção popular, originada dos cortejos dionisíacos, procurava algo que pudesse lhe servir de complemento e medida:

A história da gênese da tragédia grega nos diz agora, com luminosa precisão, que a obra de arte trágica dos helenos brotou realmente do espírito da música: pensamento pelo qual cremos fazer justiça, pela primeira vez, ao sentido originário do coro. Ao mesmo tempo, porém, cumpre-nos acrescentar que o significado, acima exposto, do mito trágico nunca se tornou transparente, com nitidez conceitual, aos poetas gregos e, ainda menos, aos filósofos gregos; seus heróis falam, em certa medida, mais superficialmente do que atuam; o mito não encontra de forma alguma a sua objetivação adequada na palavra falada. (NIETZSCHE, 1992, p. 103). 
A música dionisíaca permitiria a aproximação da imagem e da palavra para transmitir seu conteúdo de forma plástica: o mito trágico, o abandono desesperado às forças incomensuráveis da natureza. Esse seria o inaudito do espírito da música que adquire forma audível pela representação plástica apolínea. O principiun individuationes que representa o herói é imerso na sonoridade envolvente do coro que, se permite ao herói seu momento apolíneo de individuação, o faz para em seguida negá-lo e devolvê-lo ao uno dionisíaco.

Cumpre-nos reconhecer que tudo quanto nasce precisa estar pronto para um doloroso ocaso; somos forçados a adentrar o nosso olhar nos horrores da existência individual - e não devemos, todavia estarrecer-nos, um consolo metafísico nos arranca momentaneamente da engrenagem das figuras mutantes. Nós mesmos somos realmente, por breves instantes, o ser primordial e sentimos o seu indomável desejo e prazer de existir; a luta, o tormento, a aniquilação das aparências se nos afiguram agora necessários, dada a pletora de incontáveis formas de existência a comprimir-se e a empurrar-se para entrar na vida, dada a exuberante fecundidade da vontade do mundo; nós somos trespassados pelo espinho raivante desses tormentos, onde quer que tenhamos tornado um só, por assim dizer, como esse incomensurável arquiprazer na existência e onde quer que pressintamos, com êxtase dionisíaco, a indestrutibilidade e a perenidade desse prazer. (NIETZSCHE, 1992, p. 102).

O herói é apenas figuração e a sua negação no palco da tragédia é o retorno dele e do público aos fundamentos do ser, ou seja, ao trágico que o coro não permite esquecer nem um só momento, pois entoa um canto a Dionísio, esse o verdadeiro herói que sobrepuja as aparências apolíneas. O próprio coro lembra que o indivíduo encontra-se imerso no uno, o coro é a representação plástica dessa unidade, a negação do indivíduo na pessoa do herói. O que não é feito com tristeza, com pesar, mas com muita alegria, a embriaguês dionisíaca é a da entrega e da comunhão existencial com a natureza, com o uno primordial. O prazer seria a verdadeira "katharsis de Aristóteles, que os filólogos não sabem se devem computar entre os fenômenos médicos ou morais.” (NIETZSCHE, 1992, p. 133). Esse pathos em seu mais alto grau é atingido no fenômeno estético baseado no jogo das forças apolíneas e dionisíacas, promovendo um incomensurável prazer que afirma a vida em sua essência trágica.

A representação trágica seria a forma mais apropriada, não só de unir música e palavra, mas de expressar o inaudito de forma a proteger o indivíduo da rudeza da realidade natural. Baseados nela, os humanos podem contemplar o divino sem se queimar na infinita luminosidade dos deuses. ${ }^{18}$ Dionísio conseguira, tal como Prometeu, presentear ao humano com uma dádiva: vislumbrar o divino sem a morte súbita, como ocorrera com sua mãe. Ainda mais, esquecer-se de si e reconhecer-se no divino Uno-natural. O arrebatamento provoca a katarsis por meio da completa descarga patética do dionisíaco no apolíneo. Nas palavras de Nietzsche: 
Nos termos desse entendimento devemos compreender a tragédia grega como sendo o coro dionisíaco a descarregar-se sempre de novo em um mundo de imagens apolíneo. [...] O coro da tragédia grega, o símbolo do conjunto da multidão dionisiacamente excitada, [...] é a mais alta expressão da natureza e profere, como esta, em seu entusiasmo, sentenças de oráculo e sabedoria; como compadecente, ele é ao mesmo tempo o sábio que, do coração do mundo, enuncia a verdade. Assim surge aquela figura fantástica e aparentemente tão escandalosa do sábio e entusiástico sátiro, que é concomitantemente “o homem simples” em contraposição ao deus: imagem e reflexo da natureza em seus impulsos mais fortes, até mesmo símbolo desta e simultaneamente pregoeiro de sua sabedoria e arte músico, poeta, dançarino, visionário, em uma só pessoa. (NIETZSCHE, 1992, p. 61-62).

Ao mesmo tempo homem simples e deus. Síntese, entre os impulsos dionisíacos e a figuração apolínea. Sem dúvida, os gregos poderiam ensinar aos contemporâneos, pensava o jovem Nietzsche leitor de Wagner. Aos contemporâneos corrompidos culturalmente pelo Estado em seu afã de educar a nação. Corrompidos especialmente pela decadência estética imposta pelo domínio da palavra e da crítica expressa na Ópera. Tal como analisava Wagner em Ópera e Drama. Não é sem propósito que Nietzsche dedica vários parágrafos de $O$ nascimento da tragédia para analisar a ópera e sua inoperância estética.

\section{$\hat{E}$ xodo}

Para Nietzsche, a tragédia grega não morreu de morte natural, mas foi assassinada pela filosofia racionalista de Sócrates e de seu representante na tragédia, Eurípides. Nietzsche menciona isso em $O$ drama musical grego e, incisivamente, valendo-se do décimo primeiro parágrafo de $O$ nascimento da tragédia. Eles teriam inaugurado uma cultura da ópera em que a palavra (logos) sobressai-se à música e ao pathos. O êxtase dionisíaco, descarregando-se no jogo apolíneo de imagens, é substituído por uma tendência extra-artística o recitativo (NIETZSCHE, 1992, p. 112). Assim, o coro é substituído pelo canto lento e claro do herói que objetiva tornar totalmente claro seu discurso. A música adquire função de segundo plano e a linguagem dominante passa a ser a palavra que deve ser clara, objetiva e racional. A organização que se instaura no palco separando música, palavra e cena, para Nietzsche, é algo extremamente artificial. Por isso, para ele, a origem desse processo é extra-artística e se encontra na filosofia socrática e na tragédia de Eurípides. (NIETZSCHE, 1992, p. 112).

Modernamente, a ópera seria o representante dessa decadência e forma antinatural, própria de uma civilização socrática de entender a arte. Retomando as considerações de Wagner acerca da 
ópera italiana em Ópera e Drama, Nietzsche reconhece esta ênfase na palavra e o consequente distanciamento com relação ao ouvinte.

Ao ouvinte que deseja captar com nitidez a palavra sob o canto corresponde o cantor, pelo fato de falar mais do que cantar e de aguçar nesse semicanto a expressão patética da palavra: por meio desse aguçamento do pathos, ele facilita a compreensão da palavra e subjuga aquela metade da música ainda restante. (NIETZSCHE, 1992, p. 113).

Ao ouvinte cabe entender objetivamente o conteúdo sem envolver-se, muito menos ser arrebatado com a representação. Trata-se do ocaso da tragédia e da música e a utilização da ópera e da palavra como espelho do mundo. Para Nietzsche isto, assomado à qualidade do público que frequentava os teatros de seu tempo, era decorrente da decadência cultural em que se encontravam os alemães seus contemporâneos. Entretanto, havia a esperança de uma nova tragédia e uma nova cultura, um renascimento da tragédia no espírito da música a partir da obra de Wagner. Essa esperança foi mais forte no final da década de 1860 e no início de 1870 e parece ter-se conservado até o Festival de Bayreuth. ${ }^{19}$ Entrementes já são notadas, nos escritos de 1874 e na Quarta Intempestiva: Richard Wagner em Bayreuth, algumas reservas acerca do empreendimento desejado por Nietzsche a ser liderado por Wagner. Talvez esses significados sejam os mais marcantes da leitura que o jovem Nietzsche fez de seu "Pater Seraphice".

\footnotetext{
${ }^{1} \mathrm{O}$ presente texto é parte adaptada e revisada de minha tese de doutoramento defendida no ano de 2005, junto ao Programa de pós-graduação em História da UNESP-Assis, sob orientação do professor Dr. Hélio Rebello Cardoso Jr.

${ }^{2}$ Todas as cartas foram traduzidas por mim a partir da edição francesa das obras completas de Nietzsche e comparadas com a versão em alemão: Sämtliche Werke. Kritische Studienausgabe. 15 v. Herausgegeben von Giogio Colli und Mazzino Montinari. Berlim/München: Walter de Gruyter \& Co., 1988.

${ }^{3}$ Trata-se de alguns dos adjetivos utilizados pelo jovem Nietzsche ao se dirigir a Friedrich Ritschl em suas cartas nesse período.

${ }^{4}$ Em Ecce Homo Nietzsche afirma que: "A partir do momento que apareceu uma edição para piano de Tristão e Isolda (os meus cumprimentos, Her von Bülow!), tornei-me um wagneriano confesso.” Mas sua irmã nota que o encontro com essa obra de Wagner se deu muito mais cedo, no inverno de 1862, quando, valendo-se dos fundos reunidos pelos amigos Friedrich, Pinder e Krug para sua sociedade cultural, a Germania, adquiriram um exemplar da publicação, Zeitschrift für Musik, a única que apoiava a causa wagneriana na Alemanha. Reuniam-se para tentar executar obra, bem como para discutir as relações entre música e poesia. Teria sido nesse momento que Nietzsche, segundo Elizabeth Nietzsche, teria sentido pela primeira vez, o poder arrebatador da música wagneriana. Cf. NIETZSCHE, F. Correspondência com Wagner. Apresentada por Elizabeth Foerster-Nietzsche. Trad. Maria José de La Fuente. Lisboa: Guimarães Editores, 1990.p. 15-17.

${ }^{5}$ Mesmo após ter rompido teoricamente com Wagner, o que ocorre definitivamente após o Festival de Bayreuth, Nietzsche iria reconhecer o valor da convivência e da amizade significativa com Wagner. E um pouco antes de seu colapso mental, em 1888, escreveu as seguintes palavras: "Aqui onde falo das influências vivificantes da minha vida, é necessária uma palavra para exprimir a minha gratidão pelo que, acima de todas as coisas, me revigorou mais profunda e genuinamente. E isso foi, indiscutivelmente, a minha convivência com Richard Wagner. Todas as minhas restantes relações de amizade são por mim tratadas muito ligeiramente, mas por preço algum estaria disposto a apagar da minha vida os dias de Tribschen - esses dias de confidência mútua, de agradável disposição, de sublimes lampejos - os momentos profundos...” Cf. NIETZSCHE, F. Correspondência com Wagner. Apresentada por Elizabeth Foerster-Nietzsche. Trad. Maria José de La Fuente. Lisboa: Guimarães Editores, 1990. p. 11-12.

${ }^{6}$ Carta de Wagner a Nietzsche: maio de 1872.
} 
${ }^{7}$ Carta de Rohde a Nietzsche: dezembro de 1869.

${ }^{8}$ Uma tentativa de periodização nos é sugerida pelo próprio Nietzsche em Richard Wagner em Bayreuth $\S 2$, que o faz levando em consideração a inspiração teórico-estética de Wagner, o Feurbachiano e o Schopenhaueriano. Em $O$ caso Wagner, Nietzsche, mais uma vez, fará essa distinção com base nos conceitos de beleza e de sublime, que seriam dominantes na obra de Wagner, respectivamente a essas duas fases.

${ }^{9}$ Neste sentido, torna-se ilustradora para nós a tese de doutoramento de Iracema Maria de Macedo Gonçalves da Silva que, ao analisar a trajetória intelectual de Wagner, classifica didaticamente a produção do músico em distintos momentos. Para ela, poderíamos dividir didaticamente o trabalho de Wagner em seis períodos: primeiro: 1834-1838 nesse momento Wagner produz ensaios sobre questões diversas relacionadas à arte e as publica em jornais especializados; segundo: 1839-1842 - continua publicando em jornais musicais e produz dois escritos: Uma peregrinação a Beethoven e $O$ fim de um músico estrangeiro em Paris, este último baseado em sua própria experiência naquela cidade; terceiro: 1842-1847 - inicia um esboço autobiográfico (Minha vida) e escreve artigos sobre Beethoven, Mendelssohn e outros músicos; quarto: 1848-1849: escreve uma série de artigos de orientação revolucionária, criticando, sobretudo o teatro de seu tempo por sua precária autenticidade e as necessidades de reforma do mesmo; quinto: 1849-1851 - é o momento do exílio em Zurique e o mais produtivo do ponto de vista teórico do músico. Os escritos estéticos que o jovem Nietzsche irá ler com entusiasmo são desse momento: A arte e a revolução; A obra de arte do futuro; Ópera e Drama e Uma comunicação a meus amigos. Além de outros escritos como Arte e clima e $O$ judaísmo na música; sexto: 1865-1880 - são desse momento os ensaios: O Estado e a religião, A arte alemã e $O$ que é alemão? Além de artigos e uma autobiografia ditada para sua esposa Cosima. Todos estes escritos têm ligação com o rei Ludwig da Baviera seu protetor e financiador. Além disso, publica Beethoven (1870) e Arte e religião (1880). Bem como uma intensa propaganda relacionada ao teatro de Bayreuth, também financiado pelo rei Ludwig. GONÇALVES DA SILVA, Iracema Maria de Macedo. Nietzsche, Wagner e a época trágica dos gregos. Tese. Campinas: Unicamp, 2003. (Tese)

${ }^{10}$ Provavelmente tenha sido também essa a causa maior do rompimento teórico entre eles.

${ }^{11}$ Curiosamente, esta será umas das principais críticas que o jovem Nietzsche remeterá a Wagner por ocasião do Festival de Bayreuth. O próprio Wagner teria se rendido àquilo que criticara quando jovem.

${ }^{12}$ Nietzsche expressou todo seu encantamento pela cultura trágica dos gregos antigos e sua capacidade de imitar elementos de outras culturas adaptando-os para suas necessidades. Ver: NIETZSCHE, F. La philosophie à l'époque tragique des Grecs. In: Écrits posthumes. 1870-1873. Textes e variants établis par G. Colli et M. Montinari. Traduits de l’allemand par Jean-Louis Backes, Michel Haar et Marc B. de Launay. Paris: Gallimard, 1975.

${ }^{13}$ Nietzsche cita a primeira parte de $O$ mundo como vontade e representação, p. 310.

${ }^{14}$ Vale destacar que a categoria predominante para pensar a música em Schopenhauer da qual são tributários Wagner e Nietzsche (até seu rompimento com Wagner) não é o da beleza, como fica explícito nessas passagens, mas a categoria de sublime. Nietzsche faz esse reconhecimento em sua Tentativa de autocrítica (o prefácio para $O$ nascimento da Tragédia)

${ }^{15}$ Nietzsche conservou, em sua biblioteca, até a sua morte, um exemplar deste texto de Wagner. Nota da edição francesa das obras completas de Nietzsche. NIETZSCHE, F. Correspondance II. Avril 1869 - Décembre 1874. p. 599.

${ }^{16}$ Ver também: NIETZSCHE, F. Correspondance I. Juin 1850 - Avril 1869. Carta 540. A Gersdorff: 06 de abril de 1867.

${ }^{17}$ No § 23, Nietzsche, tomando os gregos como exemplo, destaca uma certa função social do mito (essa expressão não é de Nietzsche) uma vez que ele fornece subsídios para estruturar a educação, os costumes, o direito e o Estado. Afirma então: "imagine-se uma cultura que não possua nenhuma sede originária, fixa e sagrada, senão que esteja condenada a esgotar todas as possibilidades e a nutrir-se pobremente de todas as culturas - esse é o presente, como resultado daquele socratismo dirigido à aniquilação do mito. E agora o homem sem mito encontra-se eternamente famélico, sob todos os passados e, cavoucando e revolvendo, procura raízes, ainda que precise escavá-las nas mais remotas Antiguidades.”

${ }^{18}$ Referência à Semele que, apaixonada por Zeus e aconselhada pela ciumenta Hera, pediu para o amante divino para que ele se mostrasse em todo o seu esplendor. Zeus querendo ser-lhe agradável o fez, o que terminou fulminantemente com a vida de Semele. Zeus, então, tira o feto que havia em seu ventre e o instala em sua coxa para terminar sua gestação. Esse filho se chamaria Dionísio.

${ }^{19} \mathrm{Na}$ obra publicada talvez a referência mais evidente a essa esperança encontra-se em O nascimento da tragédia, § 23 quando aposta em um renascimento do mito alemão a partir da música e do exemplo dos gregos. p. 136 da tradução brasileira citada. 


\section{Referências:}

DARNTON, R. História da Leitura. In: BURKE, P. A escrita da história: novas perspectivas. Trad. Magda Lopes. São Paulo: Editora da Universidade Estadual Paulista, 1992.

DIAS, R. M. A canção popular. In: Nietzsche e a música. Rio de Janeiro: Imago, 1994.

HOLLINRAKE, R. O Anel dos Nibelungos. In: HOLLINRAKE, R. Nietzsche, Wagner e a filosofia do pessimismo. Trad. Álvares Cabral. Rio de Janeiro: Jorge Zahar Editor, 1986. p. 43-58:

JAHN, O. Gesammelte Aufsätze über Musik. Leipzig, 1866.

JANZ, C. P. Friedrich Nietzsche: Infancia y juventud. vol 1. Trad. Jacobo Muñoz. Madrid: Alianza Editorial, 1978.

LEBRUN, G. Quem era Dioníso? Kriterion, Belo Horizonte, 74-75, janeiro a dezembro de 1985: 39-66.

NIETZSCHE, F. Correspondance I. Juin 1850 - Avril 1869. Textes établis par Giorgio Colli et Mazzino Montinari. Traduction de Henri-Alexis Baatash, Jean Bréjoux et Maurice de Gandillac. Paris: Gallimard, 1986.

NIETZSCHE, F. Correspondance II. Avril 1869 - Décembre 1874. Textes établis par Giorgio Colli et Mazzino Montinari. Traduction de Henri-Alexis Baatash, Jean Bréjoux et Maurice de Gandillac. Paris: Gallimard, 1986.

NIETZSCHE, F. Correspondência com Wagner. Apresentada por Elizabeth Foerster-Nietzsche. Trad. Maria José de La Fuente. Lisboa: Guimarães Editores, 1990.

NIETZSCHE, F. La philosophie à l'époque tragique des Grecs. In: Écrits posthumes. 1870-1873. Textes e variants établis par G. Colli et M. Montinari. Traduits de l'allemand par Jean-Louis Backes, Michel Haar et Marc B. de Launay. Paris: Gallimard, 1975.

NIETZSCHE, F. Sämtliche Werke. Kritische Studienausgabe. 15 v. Herausgegeben von Giogio Colli und Mazzino Montinari. Berlim/München: Walter de Gruyter \& Co., 1988.

NIETZSCHE, F. O nascimento da tragédia ou helenismo e pessimismo. Trad. J. Guinsburg. São Paulo: Cia das Letras, 1992.

NIETZSCHE, F. Schopenhauer éducateur. In: Considérations inactuelles III et IV. et Fragments Posthumes début 1874-printemps 1876. Textes et variantes établis par Giorgio Colli et Mazzino Montinari. Traduits de l'allemand par Philippe Lacoue-Labarthe et al. Paris: Gallimar, 1988.

SAFRANSKI, R. Nietzsche: biografia de uma tragédia. Trad. Lya Luft. São Paulo: Geração Editorial, 2001.

SILVA GONÇALVES DA, I. M. de M. Nietzsche, Wagner e a época trágica dos gregos. 2003. Tese (Doutorado em Filosofia) - Unicamp, Campinas, 2003.

WAGNER, R. Beethoven. Trad. Theodomiro Tostes. Porto Alegre: L\&PM, 1987. 
WAGNER, R. Dichtungen und Schiften. Jubiläumsausgabe in zehn Bänden. Dieter Borchmeyer (Org). Frankfurt am Main: Insel, 1983.

WAGNER, R. L’art y la Revolución. In: Obres teoriques y critiques. Trad. De Joaquim Pena. Barcelona: Associação Wagneriana, 1909. Texto integral também disponível no site do Arquivo Wagner: http://archivowagner.info/index.html visitado em maio de 2005.

Recebido em 01/06/2011

Aprovado em 17/08/2011. 